\title{
HasanuddinLawReview Trasnditin
}

Volume 3 Issue 3, December 2017

P-ISSN: 2442-9880, E-ISSN: 2442-9899

Nationally Accredited Journal, Decree No. 32a/E/KPT/2017.

This work is licensed under a Creative Commons Attribution 4.0 International License.

\section{The President's Power and Anti-Corruption Policy: What Can Be Learned from New Order Experience}

\author{
Oce Madril \\ Faculty of Law, Gadjah Mada University, Indonesia. E-mail: ocemadril@ugm.ac.id
}

\begin{abstract}
ARTICLE INFO
Keywords:

Anti-Corruption; Legal

Policy; President Power

How to cite:

Madril, O. (2017). The

President's Power and

Anti-Corruption Policy:

What Can Be Learned

from New Order

Experience. Hasanuddin

Law Review, 3(3): 307-321

DOI:

10.20956/halrev.v3i3.1318
\end{abstract}

\begin{abstract}
The New Order government led by President Soeharto was supposed to be a regime that would ameliorate the abuse of power conducted by the previous government. One of the important agendas for the New Order government was overcoming the issues regarding the abuse of authority and corruption in the government sector. Several legislations, Presidential legal policies and institutions were formed to carry out such mission. However, the New Order government eventually failed and became a corrupt regime. This study concludes that notwithstanding Indonesia theoretically had an institutional framework to combat corruption under the New Order government, it failed to eradicate corruption. The failure of anti-corruption policies under the New Order era was caused by 3 forms of failure. Firstly, the failure to build a democratic and anti-corruption presidential power. Secondly, the failure to build a comprehensive anti-corruption policy. Thirdly, the failure to build an effective anti-corruption agency. The method employed in this study is a combination of several approaches between the statutory approach, historical approach and conceptual approach. The main data used in this study is the literature which are consists of previous research, legislation and Presidential policies.
\end{abstract}

Copyright (C) 2017 HALREV. All rights reserved.

\section{Introduction}

The New Order is the antithesis of the Old Order. Indonesia has a reputation as one of the most corrupt countries in the world. Hence, the new order means a total correction of the old order. ${ }^{1}$ In his first speech on August 16, 1967 before the Gotong Royong People's Assembly, Acting President Soeharto stated that the purpose of the establishment of the new order reign was a complete correction of all forms of misconduct perpetrated by the previous government. ${ }^{2}$ The speech contained a harsh

1 McLeod, R.H. (2000). “Soeharto's Indonesia: A Better Class of Corruption”. Agenda: A Journal of Policy Analysis and Reform, 7(2): 99-112.

2 Dipodisastro, S. (1997). Tritura dan Hanura, Perjuangan Menumbangkan Orde Lama dan Menegakkan Orde Baru. Jakarta: Yanense Mitra Sejati, p. 27-28. 
criticism against administration system under President Soekarno's term which was called as "old order". The Order that was considered to be fraught with deviations, misappropriation of Pancasila and a perversion of the constitution. The order was also considered to be fraught with corruption, self-enrichment, and exploit state power for the benefit of the individual and a handful of groups close to the ruler. ${ }^{3}$

The issue of corruption eradication is a fairly popular issue at the beginning of the New Order government. At the end of 1967, students spearheaded demonstrations demanding the government to increase corruption eradication efforts. ${ }^{4}$ Then, the public pressure has made the government focus on efforts to eradicate corruption. The President's anticorruption commitment is reflected in various state speeches. On various occasions, Suharto asserted the importance of eradicating corruption. ${ }^{5}$ Soeharto's anti-corruption commitment was reinforced by the political support of the Provisional People's Consultative Assembly (MPRS). The country's highest institution issued a Decree (Ketatapan MPRS) mandating Suharto to take steps to clean up the state apparatus from deviations. ${ }^{6}$

In the early years of his reign, President Soeharto's anticorruption commitment deserved to be appreciate. At least this commitment is evident from various anticorruption statements spoken in official speeches. In addition, there were several teams and institutions established to improve the effectiveness of corruption eradication. For example, the Corruption Eradication Team established in 1967, Commission 4 formed in 1970 and the Orderly Operation in 1977. The effort to eradicate corruption in the New Order era was accompanied by the idea of development. Corruption is considered to threaten the achievement of the ideals of the new order. However, these anticorruption policies have no impact on the decreasing level of corruption. Strong criticism was launched against President Soeharto who was seen as failing to eradicate corruption. President Soeharto was seen to be involved in a vortex of corruption, he himsefl carried out, his family, his cronies, especially the military (army). ${ }^{7}$

Corruption during the New Order period can go a long way because of the subjective consciousness of entrepreneurs who rely on the state by becoming a businessmenpoliticians. Implementation of development policies is largely controlled by and through state bureaucratic mechanisms that form as "physical capital accumulation" which basically perpetuates corrupt practices. ${ }^{8}$ This led to a massive bureaucratic corruption. In addition to administrative corruption, ${ }^{9}$ according to Artidjo Alkostar, 10 the New Order regime also involved in political corruption through the making of legal instruments that legalized its corrupt practice. Through legal instruments such as

\section{Ibid.}

4 The Eradication of Corruption, Formation of Law No. 3 of 1971. Direktorat Jenderal Pembinaan Hukum Departemen Kehakiman, p. 42

5 Pudjiarto, S.H. (1994). Politik Hukum Undang-Undang Pemberantasan Tindak Pidana Korupsi di Indonesia Yogyakarta: Universitas Atma Jaya Yogyakarta, p. 33-34

6 TAP MPRS No. XLIII/MPRS/1968 on the Elucidation of Decree MPRS No. IX/MPRS/1966.

7 See Crouch, H. (1978). Army and Politics in Indonesia. Cornell University Press.

8 Deni, S. (2010). Korupsi Birokrasi: Konsekuensi, Pencegahan \& Tindakan dalam Etika Administrasi Publik. Yogyakarta: Naufan Pustaka, p. 178.

9 According to Dahlstorm, administrative corruption could be also called as petty corruption or streetlevel corruption, is corruption by government officials who are usually in the form of bribery or extortion received from parties dealing with government, due to licensing or other forms of service. See Dahlstorm, C., and Victor, L. (2011). Myths of Corruption Prevention, What is (not) Good With a Weberian Bureaucracy?. APSA 2011, Annual Meeting.

10 Alkostar, A. (2008). Korupsi Politik di Negara Modern. Yogyakarta: FH-UII Press, p. 83. 
"Presidential Decree", Soeharto makes policies that benefit only the families and his cronies. The presidential decree was considered perverted because it was issued to smooth the business of Soeharto's family and colleagues.

\section{President Soeharto and the Executive Heavy}

President Soeharto's original mission was to consistently uphold the law and constitution. President Soeharto wanted to build a government based on constitutional principles. There were many abuses of the legal and constitutional law from the proceeding government that the New Order wanted to correct. This commitment was evident from various political speeches delivered by the President and the legal policies published at the beginning of his term.

Sebastian Pompe wrote that President Suharto tried to restore the principles of the rule of law in the early days of his reign. In a speech in front of the Assembly Session in 1966, President Soeharto expressed his determination to rectify the interpretation of the 1945 Constitution. Such phenomenon was met with high expectations from the judges, lawyers, and legal academics during that era -Soeharto would strengthen the rule of law. ${ }^{11}$

However, such commitment eventually faded. Instead of restoring the rule of law, President Soeharto ended up using the same personal rule model that was used by his predecessor, President Soekarno. Angus McIntyre said that this particular Soehartoesque personal rule began when the President started to accumulate power. The accumulation of power was centralized on the President, thus creating a dominant presidential power over the other branches of power (executive-heavy).

As a result, this phenomenon became more solid since the 1970's, when the general election began. The President formed a political party, the Golongan Karya (Golkar) and forced other political parties to merge into two parties. The first political party, Partai Persatuan Pembangunan (PPP) represented the Muslim crowd, while the second political party, Partai Demokrasi Indonesia (PDI) represented the secular crowd. Golkar always won the elections by a landslide, with a very significant number (above $70 \%$ ).

Since then, the President had full control on the political sector. The parliament was also ruled by the President. Being the President's party, Golkar had control over the House of Representatives by dominating more than $50 \%$ of the total seats (between 257 to 325 seats). Combined with the seats in the armed forces (ABRI), 75 of the total members in each period was appointed by Soeharto. With Golkar and the armed forces, the President controlled $75 \%$ of the parliamentary. Such domination rendered the House of Representatives unable to function well, thus becoming an institution that only served to give stamps of approval on the President's policies. Aside from the parliament, President Soeharto also co-opted other branches of power as well.

Executive heavy governance expanded to bureaucracy, on both central and local levels. "The President's people" ruled the bureaucracy. Executive heavy governance gave the President maximum, indefinite discretionary and control over the parliament. This accumulation of power ultimately resulted in the involvement of the "cendana" family and its cronies. New Order government's bureaucracy grew into a corrupt institution. Bureaucracy polity during Soeharto's era was not compensated with good governance.

11 Pompe, S. (1996). The Indonesian Supreme Court, Fifty Years of Judicial Development. (Dissertation). Leiden University, p. 59. Compare to Harman, B.K. (1997). Konfigurasi Politik Kekuasaan Kehakiman. Jakarta: ELSAM; Asrun, M. (2004). Krisis Peradilan, the Supreme Court under Soeharto. Jakarta: ELSAM. 
In Soeharto's Indonesia, monopolies were deliberately created, and accountability was eliminated with the conscious intention of perpetuating monopoly and discretion. In the view of Chehabi and Linz, what President Soeharto did was building a "sultanic regime". In a "sultanic regime", the dividing line between the state and the governing regime (and its cronies) is not clear. The governing regime and its cronies can directly intervene in state and government structures and ignore legal, administrative and ethical norms of government for its own benefits. ${ }^{12}$

Consequently, executive heavy caused bureaucratic corruption and the emergence of policy corruption. As explained by Artidjo, corruption occurs through the establishment of law that legalize their corruptive actions. Through legal instruments such as the President's Decree, Soeharto created policies that are only beneficial for his family and closest allies (cronies). ${ }^{13}$ Soeharto used corruption as an instrument to protect his power and win political battles. In this regard, it is interesting to note that McIntyre and Crouch stated that corruption is part of Soeharto's strategy to maintain his power and ensure the loyalty of the New Order's most important allies, namely the army, the bureaucracy, and Golkar, also known as ABG (ABRI, Birokrasi, Golkar). For example, the military personnel's were seated in civilian positions for easy access to state property, or to conduct business with bureaucratic assistance that will facilitate permits, contracts, credit grants and more. ${ }^{14}$

Liddle describes the New Order as a steeply ascending pyramid, with Suharto on its peak. Soeharto secured his dominant position not only through repression, but also through co-option. The main strategy for co-option is patronage. Suharto became a patron for elements of the New Order government. ${ }^{15}$ While in Michael Vatikiotis' view, Soeharto's power was not only sustained by the power of force, but also the power of money. In other words, Soeharto was capable of buying his allies' loyalty through various forms of assistance that enabled his reign of power for so long. President Soeharto ensured that the benefits of corruption was widely spread through the pyramid scheme and that the bureaucrats had stock in every level, so the pyramid remained solid. Even though anti-corruption campaigns were still actively brought about and the abuse of power by the government was being eradicated, the policy did not last long (temporary) because corruption quickly crept back. ${ }^{16}$

The accumulation of power centered on the President affected the President's resolve to eradicate corruption and abuse in the government body. As the Mandatory of the Assembly, the President no longer heeded the Assembly's orders. The Broad Outlines of State Policy (Garis-Garis Besar Haluan Negara, abbreviated as GBHN), which was supposed to function as a guide on the political direction of the law was not referenced to during the making of the President's policy. The eradication of corruption and abuse of authority that had always been a priority in the GBHN was ignored by the President.

12 See Chehabi, H.E., and Linz, J.J. (1998). Sultanic Regimes, Johns Hopkins University Press, Maryland

13 Alkostar, A. Op. Cit., p. 83.

14 McIntyre, A. (2005). The Indonesian Presidency, The Shift from Personal Toward Constitutional Rule. Lanham USA: Rowman and Littlefield Publishers, p. 25-29. See also Crouch, H. (1978). Army and Politics in Indonesia, Cornell University Press.

15 Liddle, R.W. (1985). Soeharto' s Indonesia: personal rule and political institutions, Pacific Affairs, 58(1), p. 71.

16 Vatikiotis, M. (1993). Indonesian Politics under Suharto: Order, Development and Pressure for Change, London: Routledge, p. 52. See also Snape, F.R. (1999). Corruption, Collusion and Nepotism in Indonesia. Third World Quality, 20 (3): 589-602. 
The President's anti-corruption legal policies were only visible during the early days of his reign. Those anti-corruption policies were not even effective. For example, the policy on the transparency of the state officials' wealth had substantial weaknesses and could not be effectively executed, and also the recommendations from Commission 4 were not fully followed up by the government.

\section{The Problems of Anti-Corruption Legal Policies}

A good law is an important factor in determining whether the eradication of corruption is going well or not. This section provides an analysis on the anti-corruption legal measures taken by the President during the New Order regime. The New Order government inherited anti-corruption legislations from the Old Order era, namely the Government Regulation in Lieu of Law No. 24 of 1964. The regulation was actually an emergency rule established by Soekarno to fill the legal vacuum in eradicating corruption. The Commission 4 review -which was set up by President Soehartoconcluded that the Government Regulation was insufficient and needed to be replaced. The government drafted a bill to eradicate corruption, which was then passed into Law No. 3 of 1971 on the Eradication of Corruption.

Above all, this law strengthened the criminalization of corruption that had been established since the era of the Old Order. This law also had a broader scope which set several new standards, for example it included the abuse of authority committed by government officials as an act that could be charged with corruption. Attempts to criminalize corruption was reinforced by the presence of Law Number 11 of 1980 on the Crime of Bribery. This law specifically regulated the prosecution of bribery. This law could be considered as the lex speciali of the law on the Eradication of Corruption. The law was noticeably very short, consisting of only 6 articles. This law was designed to complement the existing relevant rules and to give law enforcers a wider range in prosecuting bribery.

Both acts made by the New Order President had repressive characters. Those law purely functioned as a legal basis in strengthening the criminalization of corruption and bribery, and the law enforcement mechanism. There were provisions regarding the prevention of corruption itself. The preventive measures promised by Soeharto did not appear in both the law and the draft, whereas according to the recommendations made by Commission 4, corruption issues should be comprehensively covered through criminalization of the act itself and preventive efforts.

The government should have developed a comprehensive anti-corruption legislation, namely regulations governing the implementation of the law's enforcement and prevention of corruption, as the legal basis for the birth of anti-corruption policies in the New Order era. However, even without a strong legal coverage, President Soeharto had notably issued several policy initiatives relating to the prevention of corruption in the government's administration, starting with the policy on the transparency of the state officials' wealth through the issuance of the Presidential Decree No. 52 of 1970 on the Registration of the Personal Wealth of State Officials/Civil Servants/the Armed Forces.

At a glance, this legal policy can be seen as the anti-corruption policy that many international agencies recommended. This policy was also known as the public officials' personal wealth transparency through declaration of assets. In addition to strengthen the principle of transparency, this policy was also used to monitor unfair accumulation of public officials' wealth. 
However, the policy formulated by President Soeharto was different from the policy containing declaration of assets. The policy ignored the basic principle of transparency because the state officials' wealth was declared confidential and the government forbade the publication of the data. Such confidentiality and closure regarding the state officials' wealth was affirmed with a Presidential Decree, and there were sanctions for parties who try to publicize the data. It should not be surprising, then, that this policy ultimately did little to no help in preventing corruption in the government.

Another policy model initiated by the New Order government to prevent corruption was by strengthening the oversight of corruption. As explained earlier, the New Order government initiated several models of supervision, both within the scope of ministries and government agencies or outside of said ministerial and agencies structures. The President even established specialized institutions, such as the State Development Audit Agency (Badan Pengawasan Keuangan dan Pembangunan, abbreviated as BPKP) and a particular ministry that oversaw government surveillance.

Although the government had established several mechanisms to carry out the function of control over the governance, irregularities and corruption still occurred. According to Emil Salim, Minister of State for the Development and Conservation of the Environment during the era, corruption became even harder to eradicate. ${ }^{17}$ The model of layered control and surveillance used during the New Order era was ultimately not effective enough to prevent irregularities in the government administration. The failure of these supervisory institutions could be attributed to several factors.

The first thing is related to authority. As seen from the legal basis, each supervisory institution had its own supervisory functions. The main issue of such supervisory institutions was that they had a limited range of authority. Its authority was limited to carry out examinations, and the result of those examinations would be used by the other institutions. For example, the Inspectorate General of Development, which was in charge of overseeing construction projects, worked for the President and submitted the result of its examination to the President. The State Development Audit Agency also submitted its examination result to the President. In addition to the President, there were also certain ministerial agencies, department, or other government agencies that were responsible for several supervisory institutions and had the rights to receive their examination results.

Those supervisory institutions had no power to ensure that their findings would be acted upon, thus resulting in dysfunctional institutions that could not perform their functions well. Furthermore, the authority of a supervisory institution was only regulated on a general, wider term, allowing an open interpretation on operational level according to the wishes of the respective leaders of those institutions or departments. Ultimately, the optimization of the supervisory function in government bodies depended on how the leader of an institution wanted it to be.

The second factor is the dependence on President's political will. Several supervisory institutions were directly coordinated by the President, like the Inspectorate General of Development and the State Development Audit Agency whose examination results were directly submitted to the President. This might have caused some issues since the follow-up of those reports depended on the President. There was no mechanism to

17 Sjoekoer, A. (1998). Korupsi, Kolusi dan Nepotisme Era Pemerintahan Soeharto. Jakarta: Yayasan Pustaka Grafiksi, p. 20. 
ensure that the reports from those institutions would be acted upon accordingly. The President had the last words on the reports. It was not a rare occurrence that those examination results just vanished from the President's hands instead. This dependence on the President's attitude and will might have paralyzed the supervisory institution because they could not ensure that their findings would be used to fix the bureaucracy as it should be.

The third factor is the fact that supervisory institutions were non-autonomous. Such position rendered them unable to create independent decisions. For example, an internal supervisory body of a ministerial department was also part of the department itself, thus making it difficult to conduct objective supervision. Even more so if a supervisory institution was under a Minister, Secretary General, or other echelon I officials - they would not dare to make firm decisions. Supervisors became less comfortable in doing their job because there was a sense of ewuh-pekewuh (reluctance) in examinations. The rise of esprit de corps also factored in making the supervisory officials unwilling to report their examinations objectively and transparently.

The fourth factor is the overlapping and duplication of institutes caused by the number of varying internal control mechanisms. This overlapping and duplication caused uncertainty over which authority was authorized to supervise. Each institution felt like it had the authority to conduct the examination, causing confusion among the government bodies that were supposed to be examined. An examination over one government agency might be done by two different supervisory institutions with different examination results, and this surely posed a problem because there would be a disagreement and confusion over which institution they should refer to.

These overlapping systems became even worse since there was no regulation on the working mechanism and coordination among supervisory institutions. Bob Ronald F. Sagala stated that there was a disharmony between the government's internal supervisory institutions. Each institution protected their own ego, causing a visible institutional arrogance. ${ }^{18}$ This sectorial arrogance is caused by poor coordination mechanisms among supervisory agencies. The absence of coordination between one institution and another eventually resulted in inter-agency conflicts, causing the obstruction of justice.

The fifth factor is related to human resources (HR) issues. Human resources have the most important role in supervisory institutions. The main issue was that the human resources; the employee placed in the institutions did not have the necessary competence. Often the human resources placed in supervisory institutions were employees that are marginalized and no longer needed in other fields or work, so it was only natural that the human resources in supervisory departments had a competence below the average workers ${ }^{19}$. Even worse, the human resources in supervisory institutions were the outcast or those who got sanctioned or demoted. This issue obviously correlated with the quality of the supervision or control done by said institutions. If the human resources had questionable competence, their examination results would not be considered credible.

18 Bob Ronald F. Sagala, as cited in Suseno, A. (2010). Eksistensi BPKP Dalam Pengawasan Keuangan dan Pembangunan. Jurnal Ilmu Administrasi dan Organisasi, 17 (1): 15-30.

19 Ibid., p. 22-23. 
The final factor is corruption in supervisory institutions. It's such an ironic matter, institutions that should be working to prevent corruption were actually involved in the act themselves. The occurrence of corruption in supervisory institutions was a common phenomenon during the New Order. Like corruption in other government agencies, the corruption in supervisory institutions had the same pattern. This phenomenon resulted in the loss of credibility of such institutions in performing their functions.

As a result, the President's policy to establish anti-corruption institutions also failed. Those institutions had fundamental issues since they were first established, so nothing could be done effectively and ultimately they were dissolved. This issue will be discussed in the next section.

\section{The Dominance of Military}

The military had a central position in government affairs during the New Order. The military also had a dominant role in law enforcement, including the crime of corruption. Just like in the Old Order era, the military had tremendous power or access to intervene in all kinds of government affairs. In fact, one of the criticism for the New Order government is about the magnitude of the military's role in civil affairs.

In Ulf Sundhaussen's theory, the military involvement in civil and law enforcement affairs reflects the theory of the military intervention in civil affairs. In New Order era, such military interventions were made possible because the President prioritized political stability by implementing the military command system. Soeharto introduced the "armed forces dual functions" doctrine, also known as 'Dwifungsi $A B R I^{\prime}$, in which aside from being the tool of national peace and security, the military also functions in civil and political affairs.

This doctrine was implemented by letting the military took over the strategic government positions so the President could gain easy access over them. As explained by Crouch, the majority of members from Soeharto's cabinet (The Development Cabinet or Kabinet Pembangunan) were military generals. The armed forces also had ranks in the bureaucracy as echelon officials (with positions like Secretary Generals and Directorate Generals). The military's dominant role in the central government was also reflected in the local governments. Military officers served as Governors, Regents, and Mayors.

In the parliament, the military also had a significant allowance of seats so as to form a separate faction. The military was also given the key positions in State-Owned Enterprises (BUMN). In judicature institutions, the military members even served in the Supreme Court. President Soeharto implemented a system of political rewards to the military, thus created a strong, solid bond between them and the New Order regime gained the military's unconditional support.

In addition, according to McIntyre and Crouch, Soeharto allowed corruption by the military as a strategy to protect his power and ensure the loyalty of New Order's most important ally. The military was placed in civil positions and government so they could gain easy access over state property and became able to conduct business with bureaucratic assistance that would facilitate the necessary permits, contracts, credits gain, and more. ${ }^{20}$

20 See McIntyre, A., and Crouch, H. Op. Cit, p. 25-29 
Just like in the Old Order era, the military dominated anti-corruption institutions by taking part in strategic structural positions in the institutions. In every agency ever established, the military must have been involved. At first, Soeharto tried to rebuild the law enforcement system. It was evident from the appointment of the Attorney General as the head of Team for the Eradication of Corruption which was formed in 1967. This shows an effort to restore the supremacy of law to its respective civil institution. This policy was a correction on the Old Order system which gave too much power over the military to intervene in law enforcement affair.

This effort eventually failed since the military still dominated the policymaking and enforcement of the eradication of corruption. This was evident by the composition of the Team for the Eradication of Corruption members which were mostly filled with leaders and serving military officers. The military gained even more law-enforcement function in the eradication of corruption through the establishment of Operasi Tertib (Orderly Operation, abbreviated as Opstib) in 1977. This team was directly under the military's command through the Command of Operation to Restore Security and Order (abbreviated as KOPKAMTIB).

The involvement of military in the efforts to eradicate corruption showed that the New Order's anti-corruption policy had not changed much from that of the Old Order's. Borrowing the analysis of Von der Mehden, the choice of military as a main actor in corruption eradication during the early days of New Order government cannot be separated from the military's own political trauma of the civil government's failure during the era led by Soekarno. ${ }^{21}$

According to Mehden, the military's reign in political stage is a rather common occurrence in most Asian countries. The appearance of military officers in a political stage is legitimized by the assumption that the failure of civil government creates a social, economical, and political goals that must be met after the independence is achieved. Von exemplified the failure of civil governments in Pakistan, Ghana, Burma, and Indonesia during the reign of Soekarno.

In the same way, this perspective was obviously used as an excuse to give the military a bigger role in civil governance. The New Order era proved that the assumption of civil government failure is incorrect. In fact, the military failed to carry out the mandate of ruling the government.

The failure also expanded to matters of the eradication of corruption. The involvement of military in anti-corruption agencies or teams rendered them unable to do anything because then they had to face high-ranked military officials that also served as highranked government officials in government institutions and State-Owned Enterprises where most corruptions occurred.

\section{The Problems of Anti-Corruption Agencies}

During the New Order, Soeharto formed several teams and institutions to increase the effectiveness of the eradication and prevention of corruption, namely the Team for the Eradication of Corruption or Tim Pemberantasan Korupsi in 1976, Commission 4 or Komisi 4 in 1970, the Team for Orderly Operation or Tim Operasi Tertib in 1977 and several regulatory agencies in internal government, for example the Inspectorate

21 Von Der Mehden, F.R. (1987). Politics of Developing Nations. Translated by Simamora, S. "Politik Negara-negara Berkembang". Jakarta: Bina Aksara, p. 151. 
General of each agency, the Inspectorate General of Development or Inspektorat Jendral Pembangunan (abbreviated as Irjenbang) and the State Development Audit Agency. However, these institutions faced various problems and constraints that ultimately led to their failure in carrying out the mandate to combat corruption in the government sector. The following is an analysis on the problems faced by anticorruption agencies in the reign of the New Order, starting from the President's political agenda to the strong influence of the military.

First, the issues regarding political support from the President. The New Order government seemed to have no strong political commitment to combat corruption. The President did not provide strong political support for the established institutions to proceed effectively. Even in the mid to late period of the New Order government, the President's political support on the anti-corruption agenda had been lost.

Anti-corruption agencies were indeed established, but the establishment of these institutions was more of a temporary measure used by governments to respond to public discontent. For example, the establishment of the Team for the Eradication of Corruption in 1967. The formation of this Team was based on public dissatisfaction against corruption and misappropriation committed during the Soekarno government. President Soeharto as the new leader, formed the Team to show that he was the President who would clear up the remnants of abuse of authority left by the previous government. Soeharto wanted to give a message that his presidency was the antithesis of the Old Order.

However, the team did not have enough mandate to combat corruption. This institution had issues regarding limited authority and a military-dominated membership. So in the end, this Team could not fulfil the public expectation to eradicate corruption. Only small cases were investigated, while major cases of public interest were dormant. This was also the case with the establishment of Commission 4 . The establishment of a commission consisting of public figures was the President's response to the public's disappointment with the government's lacking efforts in eradicating corruption. The president did not seem to want to risk tainting his popularity with of corruption issues. The weak political support provided by the President was further proven by the lack of attention paid to the commission's recommendation, while those studies and recommendation were compiled by credible figures based on the President's own mandate.

Second, the issue regarding legal basis. As part of Presidential policy, the majority of anti-corruption institutions' legal basis was the Presidential Decree (known as Keputusan Presiden). No institution was established on the basis of an Act. This was a fundamental issue for anti-corruption agencies in the New Order. From the perspective of the establishment of these institutions, they clearly lacked a strong legal basis. It was at odd with their enormous task to combat corruption. Having a Presidential Decree as a legal basis was very risky, because the Presidential Decree is highly dependent on the President's policy, thus making it very prone to change.

Anti-corruption policy became very volatile and ensuring its continuity became difficult. The existence of those institutions highly depended on the situation and condition of the President's political will. The Team for the Eradication of Corruption, for example, had uncertain position in the government system and no long-term existence. The position of those institutions were unclear, thus making it difficult to coordinate and deal with other government agencies that had stronger legal basis of establishment. Nevertheless, if a President does have a strong political commitment to 
combat corruption, then a Presidential Decree or Presidential Regulation can be used to create a strong institution. Especially for the government (public administration), an institution established by a President might be given the authority to execute orders from the President as the supreme head of government (Chief Executive).

The problem, as has been described above, is that President Soeharto was not the kind of President who had the political will and strong political support for the anti-corruption agenda. As a result, the great power as Head of Government was not used to support the eradication of corruption. Legal policy instruments owned by the President (Presidential Decree, Presidential Instruction, or Presidential Regulation), were not used for anti-corruption agenda. This is visible from how the published policies failed to overcome corruption in the bureaucracy. Thus, the legal basis for anti-corruption policies in the form of a Presidential Regulation, Presidential Decree or Presidential Instruction will remain strong and effective only if supported by the President's own political will and political support. But if the anti-corruption political commitment is absent, then the legal basis will be weakened and helpless against corruption.

Third, is the matter of authority. Bolongaita,22 asserts that it is not a realistic option to set up an anti-corruption agency that is not equipped with a powerful authority, because the agency will not be able to work effectively. Bolongaita's words depict the anti-corruption institutions in the New Order era. The anti-corruption institutions that were established were not equipped with strong authority to eradicate and prevent corruption in government. The authority was sometimes unclear and gave rise to multiple interpretations, which ultimately resulted in the institution being unable to perform optimally.

Team for the Eradication of Corruption, for example, was tasked to assist the government in combating corruption in a timely and orderly manner, in both repressive and preventive efforts. Such task was to be carried out through its coordinating and supervision functions over all civil and military law enforcement agencies (ABRI) in the eradication of corruption. The preventive effort was to be carried out by giving suggestions to the government regarding administrative and other actions to prevent and lessen the possibility of corruption. Such coordination and oversight was also very difficult to be done, since every judiciary instrument worked and operated on a stronger legal basis compared to the Team for the Eradication of Corruption, and had stronger position. In addition, members of the Team for the Eradication of Corruption who represented the law enforcement agencies were more likely to protect the interest of their own institution, especially the military whose political standing was way higher than the Team for the Eradication of Corruption and the Attorney General combined.

This team became ineffective because it ultimately functioned to coordinate and supervise pre-existing law enforcement agencies. This team did not act as a stand-alone institution with an independent authority to combat corruption. As a result, the team became a joint forum to discuss cases that were being handled by pre-existing institutions. The authority originally belonged to its respective institutions (namely the police, prosecutors and military police) who did get a mandate from the legislation, thus giving it a stronger legal basis while this Team did not have the original authority. Meanwhile, the pre-existing institutions themselves were tainted with corruption.

22 Bolongaita, E.P. (2010). Why Indonesia's Anti-Corruption Commission succeeds where others don't; A comparison with the Philippines' Ombudsman, U4 Issue, August 2010 No. 4. 
The Team for the Eradication of Corruption had such limited authority to take preventive steps. Its authority was limited to "give suggestions" to the government. The Team for the Eradication of Corruption could not go any further to ensure that those suggestions were accepted and considered by the government. In practice, no suggestion and recommendation of anti-corruption policies from the Team for the Eradication of Corruption that was found.

The Team failed to give significant recommendation to improve the government's administration. The Team did not fulfil the mandate to fix and improve the state administration in Indonesia. This Team was directed to coordinate actions against corruption cases. Meanwhile, improvements in governance, such as regulations, institutional, personnel reforms and many others were not given enough attention. Thus, the abuse of authority in the bureaucracy still occurred because there was never any effort in revamping the system.

Commission 4 also had similar problems-it had an uncertain position in the government, it had limited authority, and it was merely an ad-hoc commission. This commission was more of an assessment team, tasked with the research and evaluation of pre-existing anti-corruption policies. Again, the Commission submitted their research in the form of advice and consideration to the President.

This commission had limited authority, it was only authorized to give advice to the President and had no further authority to follow-up or supervise the implementation of their recommendation. Whether their advice was acted upon or not was the President's domain. In fact, President Soeharto did not consider the commission's findings and considerations seriously. The government even stated that their findings were confidential, even though the research results were eventually leaked and reported by the media. It was only after the incident that the government finally took action, and even then only one anti-corruption policy followed, namely the Presidential Decree on the transparency of the state officials' wealth. However, this policy had so many fundamental errors that it could not even be properly implemented.

There was, however, an exception in the Team for Orderly Operation. The anticorruption policies mandated to the State Minister for the Control of the State Apparatus and the Operations Command for the Restoration of Security and Order (KOPKAMTIB) could be effectively implemented. Its authority was clear - to eradicate illegal levies in the bureaucracy. Quantity-wise, the institution had handled thousands of cases and sanctioned thousands of state apparatus. However, most criticism directed at this Team highlighted the fact that only lowly employees were prosecuted, while the abuse of authority committed by the elite bureaucratic was not acted upon.

The Team's success in handling thousands of cases was not due to its authority, but because the military was involved in this team, thus resulting in a firm structure of command. The rules of military discipline were applied to government officials. Direct violations were dealt with immediately. This militaristic pattern also raised criticism, for law enforcement was done in an authoritarian way without any mechanism to a fair trial and the principles of rule of law that respects human rights.

Another weakness of this Team was that it was unable to improve the governance administration system. No regulatory or policy changes had ever occurred to support governance reform. This Team was unable to reach the administrative areas of the state, and unable to reform the governance administration. 
Fourth, the issue of independence. The principle of independence for anti-corruption institutions a guarantee of effective implementation of duties of the institution. This principle anticipates the intervention by other parties in anti-corruption agencies' line of work.

During the New Order, the established anti-corruption institutions had no independence. Institutions in general did not have the necessary independence in carrying out their duties. Interventions from various parties (both civil and military) could easily influence the implementation of anti-corruption agencies' duties. Team for the Eradication of Corruption and Team for Orderly Operation were both under strong military influence. Both institutions were dominated by the military, so that the performance of their duties was strongly influenced by the decisions of the military institution. The institution had no independence, unlike law enforcement agencies.

Fifth, the issue regarding military involvement. As explained earlier, the military had a central role in the New Order government. Not only in the government sector, the military also dominated the legal sector and anti-corruption agencies. It can be seen in the structure of the 1967 Team for the Eradication of Corruption. The composition of the advisory team and team members were dominated by military actors. The four armed forces commanders in ABRI (Commander of the Army, Navy, Air Force and Commander of the Police Force) were included in the team structure, followed by high officers from each batch of military. The military also dominated the Team for Orderly Operation through KOPKAMTIB. In fact, Team for Orderly Operation was under the control of military institutions.

Military involvement in corruption eradication team was a legacy of the Old Order. This military position was further strengthened by President Soeharto by positioning the military as a backbone of the government. The military occupied positions in the government, including law enforcement agencies -even courts. So important was the role of the military that it was also involved in the efforts to eradicate corruption.

The inclusion of the military in anti-corruption institutions was clearly a form of constitutional aberrations. The military role that dominated governmental affairs contradicted the system of government (state administration). The military, which was legally a tool of state defense and security, turned into a government apparatus that carried out administrative duties of the state. This military co-ordination of government affairs had clearly disrupted the system of government.

Military involvement was deemed necessary because so many government positions were filled by military officers, and it was also done in order to combat corruption in military institutions themselves. It seemed logical but not entirely true. This argument remains unproven in practice. There were only a very small number of corruption cases involving the military that were investigated by anti-corruption team.

Moreover, with the same logic, the high-ranking military officers in Team for the Eradication of Corruption and Team for Orderly Operation should have been able to order their subordinates in the government to take actions regarding the Teams' finding in order to improve the government administration system. But in contrast, it never happened, even though the military actors in Team for the Eradication of Corruption and Team for Orderly Operation were perfectly aware of the critical points of corruption inside the government body. 
Military involvement in various anti-corruption agencies also had no effect on the military policy agenda. The fact that the military controlled the government, parliament (DPR-MPR) and even law enforcement agencies should have been used as a momentum to encourage anti-corruption agendas in government. The policy politics of the New Order government should have placed anti-corruption agenda as a part of its priority program. However, the fact is that the dual function of the Armed Forces of Indonesia was used to strengthen the military's monopoly of power in various state and government institutions, including law enforcement agencies. The involvement of the military in anti-corruption policies did not make the military politics become more averse to corruption - it was the contrary.

The various institutional issues above have significant implications in the failure of the prevention and eradication of corruption during the New Order. Government's efforts to combat corruption from within the body of government had failed. The state-run internal supervisory agency was not able to reduce distortion and corruption. The failure of the government's internal oversight institution was due to several factors.

\section{Conclusion}

This study concludes that notwithstanding Indonesia theoretically had an institutional framework to combat corruption under the New Order government, it failed to eradicate corruption. The failure of anti-corruption policies under the New Order era was caused by three forms of failure. First, the failure to build a democratic and anticorruption presidential power. This study concludes that democratic power will create democratic policies. Democratic power also tends to produce anticorruption regulatory products that support the establishment of a clean government. This formulation is evident from the practice of the New Order government. At first, President Suharto was seen trying to demonstrate his anticorruption commitment by issuing several anticorruption policies. However, when the power of the president is too strong, the power tends to corrupt. The executive heavy turns into a corrupt executive. The practice of executive heavy has made the government power to be a corrupt power.

Second, the failure to build a comprehensive anti-corruption policy. Despite efforts to review the regulatory weaknesses of the previous regime, the President failed to follow up the policy recommendations to improve good governance. The legal policies already contain congenital defects. The policy contains elementary weaknesses, so the legal policy is failed to prevent corruption in government. Poor policy was born also influenced by the character of president Suharto's power which is gradually became a corrupt power.

Third, the failure to build an effective anti-corruption agency. During the New Order, Soeharto formed several teams and institutions to increase the effectiveness of the eradication and prevention of corruption. Consequently, these institutions faced various problems and constraints that ultimately led to their failure in carrying out the mandate to combat corruption in the government sector. The problems were starting from the President's political will to the strong influence of the military. 


\section{References}

Alkostar, A. (2008). Korupsi Politik di Negara Modern. Yogyakarta: FH-UII Press.

Asrun, M. (2004). Krisis Peradilan, the Supreme Court under Soeharto. Jakarta: ELSAM.

Bolongaita, E.P. (2010). Why Indonesia's Anti-Corruption Commission succeeds where others don't; A comparison with the Philippines' Ombudsman, U4 Issue, August 2010 No. 4.

Chehabi, H.E., and Linz, J.J. (1998). Sultanic Regimes. Maryland: Johns Hopkins University Press.

Crouch, H. (1978). Army and Politics in Indonesia. USA: Cornell University Press.

Dahlstorm, C., and Victor, L. (2011). Myths of Corruption Prevention, What is (not) Good With a Weberian Bureaucracy?. APSA 2011, Annual Meeting.

Deni, S. (2010). Korupsi Birokrasi: Konsekuensi, Pencegahan $\mathcal{E}$ Tindakan dalam Etika Administrasi Publik. Yogyakarta: Naufan Pustaka.

Dipodisastro, S. (1997). Tritura dan Hanura, Perjuangan Menumbangkan Orde Lama dan Menegakkan Orde Baru. Jakarta: Yanense Mitra Sejati.

Harman, B.K. (1997). Konfigurasi Politik Kekuasaan Kehakiman. Jakarta: ELSAM.

Liddle, R.W. (1985). Soeharto' s Indonesia: personal rule and political institutions, Pacific Affairs, 58(1), p. 71.

McIntyre, A. (2005). The Indonesian Presidency, The Shift from Personal Toward Constitutional Rule. Lanham USA: Rowman and Littlefield Publishers.

McLeod, R.H. (2000). "Soeharto's Indonesia: a better class of corruption". Agenda: A Journal of Policy Analysis and Reform, 7(2): 99-112.

Pompe, S. (1996). The Indonesian Supreme Court, Fifty Years of Judicial Development. (Dissertation). Leiden University.

Pudjiarto, S.H. (1994). Politik Hukum Undang-Undang Pemberantasan Tindak Pidana Korupsi di Indonesia Yogyakarta: Universitas Atma Jaya Yogyakarta.

Sjoekoer, A. (1998). Korupsi, Kolusi dan Nepotisme Era Pemerintahan Soeharto. Jakarta: Yayasan Pustaka Grafiksi.

Snape, F.R. (1999). Corruption, Collusion and Nepotism in Indonesia. Third World Quality, 20 (3): 589-602.

Suseno, A. (2010). Eksistensi BPKP Dalam Pengawasan Keuangan dan Pembangunan. Jurnal Ilmu Administrasi dan Organisasi, 17 (1): 15-30.

Vatikiotis, M. (1993). Indonesian Politics under Suharto: Order, Development and Pressure for Change, London: Routledge.

Von Der Mehden, F.R. (1987). Politics of Developing Nations. Translated by Simamora, S. "Politik Negara-negara Berkembang". Jakarta: Bina Aksara. 